\title{
The Semantics of TRWM IN Middle Welsh Prose
}

\author{
ELENA PARINA
}

\section{Introduction.}

Like its Goidelic cognate trom, analysed in Dereza (this volume), Welsh trwm is highly polysemous. ${ }^{1}$ In contrast to Dereza's more general approach, I discuss here in detail the usage of this adjective in one relatively short period, based on the Welsh Prose 1300-1425 corpus (Luft et al. 2013; henceforth WP). In order to make the Goidelic and Welsh data comparable, I analyse my data using the same classification of senses as Dereza. Despite some difficulties arising from the structure of the corpus used, I discuss the frequency of the usage within the four domains: experiential, parametrical, psycho-physiological and emotional. The last domain is the main focus of my attention due to the diversity of constructions in which trwm is thus used. I end by drawing some conclusions concerning the use of Celtic data in lexical typology.

\section{Data}

By taking all the morphological forms of trwm from the WP wordlist, 224 examples were gathered. I reduced the number by counting as a single example identical sentences from different manuscript witnesses of the same text (such as Gereint, Ystoria Bown de Hamtwn or Ystoria Lucidar). Law texts and translations of Historia Regum Britanniae (different versions of Brut y Brenhinedd) are methodologically difficult, since we have to define what a 'text' is. In the case of the redactions of the law

\footnotetext{
${ }^{1}$ The initial part of this research was conducted within the project "Polysemy and semantic change of adjectives in Welsh from historical and typological perspective" supported by the Alexander von Humboldt foundation, conducted at the Philipps-Universität Marburg (September 2012 to July 2015), the study of translational issues within the project "Übersetzungen als Sprachkontaktphänomene - Untersuchungen zu lexikalischen, grammatischen und stilistischen Interferenzen in mittelkymrischen religiösen Texten," supported by the Fritz Thyssen Foundation led by Prof. Erich Poppe, Philipps-Universität Marburg. An earlier version of this paper was discussed at "Amrywiaeth Ieithyddol yng Nghymru / Linguistic Diversity in Wales" (July 2014, Aberystwyth). To the participants of this conference and the Celto-Slavica 7 meeting I am indebted for comments and suggestions. I am also grateful to Oksana Dereza and Raphael Sackman, who helped at different stages of this work. My gratitude extends also to Silva Nurmio who helped me by discussing some of the examples, and to Professor Erich Poppe for his constant support and advice. Needless to say, all remaining faults are mine.
} 
texts, labelled in the Corpus as different texts, I followed this practice and counted identical examples within one redaction as one, but if the same example was found in two different redactions, I counted it as two. For Brut y Brenhinedd I chose to use the classification of versions proposed in Sims-Williams (2011: 13; see also Sims-Williams 2016). Accordingly, we have six versions in WP, since I counted identical examples within a single version as one, but as two if they were from two different versions. This reduced the number of examples to 116. I am aware that this procedure is far from perfect, but it was important to reduce the number of identical examples from Brut y Brenhinedd: otherwise the instances from a body of texts which surpasses in its popularity all other Middle Welsh texts would confuse attempts to compare the frequency of certain senses. ${ }^{2}$

\section{Semantic classification of usages.}

In what follows I retain the numbering of semantic groups and rubrication used by Dereza (this volume) to enhance comparison with the Irish data. This leads to gaps in my numeration.

\section{Experiential domain}

\subsection{Weight + physical object}

In this domain trwm characterises the weight of a physical object and means 'hard to lift or move'. We find twenty-three examples of trwm with this sense. Here is an example from Ystoriau Saint Greal:

(1) ac yn ymyl porth y dref ef a vlina6d galaath rac trymet oed y tabyl yn p6yssa6 arna6

(NLW Peniarth 11: 108r) $^{3}$

And near the gate of the town Galaath became tired, so heavily did the table press upon him.

(Williams 1987: 544)

A person can also be an object that is hard to move, as seen here in Ystoria Bown de Hamtwn:

(2) Sef a wnaeth bo6n yna dachymygu kelwyd a dywedut ry dr6m 6yf $i$ ac ny diga6n e hunan yn d6yn a dabre ditheu o'e gymorth ef.

(NLW Peniarth 5: 127r)

\footnotetext{
${ }^{2}$ I am fully aware that there are alternatives to this methodology: cf., e.g., works on the thirteenth-century prose corpus (Isaac et al. 2013) ignoring multiple occurrence of the same texts, such as Höijer (2014) and Griffith (2017).

${ }^{3}$ Examples are quoted from WP unless otherwise specified. In examples from WP, worddivision and punctuation are often modified. Translations are mine unless otherwise specified.
} 
Then Bown plotted deceit and said: I am too heavy and he cannot carry [me] himself, but come to his help.

Cf. in French:

Boefs le oi si prent a degaber;/ Boefs li ad dist: "Beau duz sire eher,/ jeo sui si pesaunt que il ne me poet porter,/ mes, sire, si vits plest, car li venez eider."

(Stimming 1899: 42)

Boeve heard him and set out to fool him; Boeve said to him: "My dear, gentle lord, I am so heavy, he can't carry me; but, my lord, please come and help him."

(Weiss 2008: 45)

The majority of the objects in this group are weapons. These fall into two categories, one being different types of weapons (swords or sticks), and the other the set phrase arfau trwm (or arfau trymyon). I will start with the first one.

Bown de Hamtwn provides an example where the difficulty for a person to carry and move this object is made clear (as in the previous example, we have trwm for the French pesaunt (Stimming 1899: 29)):

(3) ry anesm6yth y6 dy varch di a ry dr6m y6 dy gledyf. ac 6rth hynny mi a baraf yt palfrei esm6yth a chledyf ysgafyn megys y gellych yn ddirbystyr kerdet ragot.

(NLW Peniarth 5: 125r)

your horse is too restless and your sword is too heavy, and therefore I will arrange for you a gentle palfrey and a light sword so that you will be able to proceed unhindered.

But trwm can also be one of the standard epithets for a sword or another kind of weapon, also met with in poetry, as discussed by Day (2010: 308, n. 667, 354). Breuddwyd Rhonabwy provides a prose example:

(4) A chledyf mawr trwm trichanawl yn y law

(Richards 1948: 13)

And he had a large, heavy, triple-grooved sword in his hand

(Davies 2007: 221)

Most frequent in this category is the set phrase arfau trwm (or, with agreement, arfau trymyon). 
(5) Ac y'r lle yd oed y uarch y doeth gereint, ac yd oed y uarch yn gyweir o arueu tr6m ystrona6l gloy6.

(Thomson 1997: 26)

Geraint came to where his horse was, and his horse was equipped with foreign, heavy, shining armour.

(Davies 2007: 159)

This formula is discussed by Day (2010: 486-7, n. 271) and earlier in detail in Reck (2010: 112-3), who suggests that the references to heavy armour as foreign and outlandish indicate that it was "considered (and perhaps deliberately so, if it was regarded as a luxury item) as a foreign element in Welsh culture" (Reck 2010: 113).

\section{Parametrical domain}

Most often in this domain, trwm functions as an intensifier, or, in the terminology of Igor Mel'čuk, has the value of the lexical function Magn (see Mel'čuk 1998: 32ff).

\subsection{Sleep}

Sleep is characterized by the adjective trwm five times in different texts, and is here cited from Brut y Brenhinedd:

(6) ac ual yd oed yn rbyga6 moroed gyt ac aneiryf o logheu mal abr hanner nos y dyg6yda6d hun trom ar arthur.

(NLW Peniarth 46: 300)

and as he was splitting seas with a multitude of ships, at midnight deep sleep overcame Arthur.

Cf. in Latin:

Dum autem innumeris nauibus circumsaeptus prospero cursu et cum gaudio secaret, quasi media hora noctis instante grauissimus sompnus eum intercepit.

(HRB X 164: pp. 222-3)

While he was ploughing the waves with his huge fleet, enjoying safe passage, at about midnight he fell into a deep sleep.

It is worth noting that in Modern Welsh trwm is still the default intensifier for sleep: cf. Griffiths, Jones (1995), s.v. sleep. 


\subsection{Density + layer, substance: 'dense, thick'}

The combination of trwm with substances having comparatively great physical weight or density, could be also included in the first experiential domain, even though no experience of movement is involved. However, in order to maintain coherence with Dereza (this volume) I will discuss such examples here. Four examples of such a kind are found in our corpus, all in Delw y Byd, the Welsh translation of Imago mundi by Honorius of Autun (see Lewis \& Diverrès 1928; Falileyev 2010; Petrovskaia 2013). In three cases we see here the comparative weight of substances (earth against other elements or saltwater against freshwater), which determines the lower position of the heavier substance: Welsh trwm and ysgafn correspond in each case to Latin gravis and levis respectively.

(7) A chanys trymaf onadunt yw y dayar, y mae yn issaf, a'r tan, kanys yscawnaf yw, a achub y lle uchaf.

(Lewis \& Diverrès 1928: 25)

And since earth is the heaviest of them [sc. the elements] it is the lowest, and fire, since it is the lightest, occupies the highest place.

The last example in this category is a combination of trwm with blood in the text Rhinweddau Bwydydd (see Parina 2015; Parina, fc.). What is interesting about this example is the presence of two different adjectives in two manuscript witnesses of the text. While Rawlinson B 467 uses trwm, Hafod 16 uses tew 'thick, fat'. In the Latin text as we know it there is no equivalent for these adjectives. It is noteworthy that this 'heavy blood' is related to melancholia, the state of being weighed down with sadness or weariness, which we shall see in the fourth domain.

(8) kic pob g6ydl6dyn anhoff y6 meithrin g6aet tr6m a melancoli a 6na, goreu hagen onadunt y6'r ierchot a'r ysgyuarnogot.

(Oxford Rawlinson B 467: 15r)

Cf.:

Kic pob gwydludyn anoff yw, meithrin gwaet tew a malencoli a wna, dyeithyr ohonunt goreu kic jyrchot ac yskyuarnogot.

(Hafod 16; Jones 1955: 62)

The meat of all wild animals is undesirable, fostering thick blood and causing melancholia, but of these the best is the meat of roebucks and hares. 
Omnis caro silvestris inlaudabilis est, melancolici sanguinis generativa; quibus tamen melior est capreolina et leporina.

(Ostermuth 1919: 41)

2.6. Significance + abstract notion: 'grave, serious'

This Magn sense is quite frequent in our sample: the combination with 'disease' is found nine times; 'crime' twice; 'sin' twice; and 'insult' once. I quote here from Rhinweddau Bwydydd and then Brut $y$ Brenhinedd (Dingestow version):

(9) Berwr, gwressawc a sych ynt; todi y fleuma a wnant a'r vygodorth drom a wnant.

(Jones 1958: 90-1)

Cresses are hot and dry; they will break up phlegm and heavy flatulence.

Nasturcium calidum est et siccum, flegma viscosum dissolvit et ventositatem grossam.

(Ostermuth 1919: 28)

(10) Ac eu herlit a vynassei vthyr megys y dechreussei ac y buassei darpar ganta6. Ac eissoes ny's gad6ys y wyrda ida6. kanys trymach uu $y$ heint arna6. A guannach no chynt uu guedy y uudugolyaeth honno.

(NLW 3036 (Mostyn 117), p. 188)

And Uther menaced to pursuit them as he began and as was his intent; however, his noblemen did not permit him, because his disease was more severe. And after this victory he was weaker than before.

In Latin we find the same phrase: quia eum grauior infirmitas post uictoriam occupauerat (HRB IX 142: p. 597, Reeve \& Wright 2007: 1903); here are examples from Llyfr Blegywryd and Ystoria Lucidar:

(11) Teir kyflafan, os gwna dyn yn y wlat, y dyly y vab colli tref y tat o'e hachaws o gyfreith: llad y arglwyd, a llad y penkenedyl, a llad y teispantyle, rac trymet y kyflafaneu hynny.

(Williams \& Powell 1961: 108)

Three felonies which, if a person commit in his own country, his son is on that account to lose by law his patrimony: the killing of his lord, and the killing of his chief of kindred, and the killing of the defender of his home, because of the gravity of those felonies.

(Richards 1954: 102) 
(12) Ae gorthr6m pecha6t? pecha6t dan wybot y vot yn becha6t. ystrymach no'r holl vyt

(Oxford Jesus College 119: 26r)

[Disciple] Is sin very heavy? [Teacher] Sin, with consciousness that it is sin, is heavier than the whole world

(Williams 1892: 696)

D. Est grave peccare? - M. Minimum peccatum scienter commissum gravius est toto mundo.

(Lefèvre 1954: 406)

2.7. Severeness + abstract notion: 'harsh, severe'

Similar is the combination of trwm with nouns meaning 'punishment' (four times) or 'vengeance'. We may consider an example from Purdan Padrig:

(13) Kann gwneuthum $i$ godyant y Duw kymeint a hynny, minneu a gymeraf benyt a vo trymach no' $r$ holl benytyeu ereill.

(Williams 1973/1974: 160)

Since I did a wrong so great to God, I will take penance that will be heavier than all other penances.

Cf. the Latin text provided by Caerwyn Williams:

Dum, ut asseris, factorem meum in tantum offensum habeam, penitentiam omnibus penitentiis grauiorem assumam.

(Williams 1973/1974: 161)

2.9. Intensity + activity, feeling, physical phenomenon, quality: 'intense / weak, not intense'

This is one of the most frequent senses in our sample, and there are two types of phrase.

In the first, trwm refers to blows or strikes (eight times). Seven examples are found in Ystoriau Saint Greal, paired three times with the adjective creulawn 'cruel'.

(14) Kei eissyoes a roi idaw ef dyrnodeu creulawn trymyon pan $y$ godiwedei.

(NLW Peniarth 11: 239v)

Kei however gave him cruel, heavy blows, when he overtook him. 
Cf. the French, Perlesvaus, line 7667:

e Kex li done de l'espee granz cox.

(Reck 2010: 187, n. 155)

and Kei deals him great buffets of his sword.

(Reck 2010: 187, n. 155)

Reck notes that in this text blows tend to be described in this way "irrespective of the vocabulary employed by the French original" (Reck 2010: 187): her thorough analysis of scenes of combat in other texts (and the results of searching WP) permit the claim that this phrase belongs to the characteristic style of the translator of Ystoriau Saint Greal.

In the same way, the phrase aerfa drom seems to occur particularly often in Brut $y$ Brenhinedd in the Dingestow version. Of the total combinations of trwm with battle (nine instances), eight are found in BB, and five in the Dingestow version, where it is used as means of brief reference to a hard battle, normally described at much greater length in the Latin original. Here I cite the Dingestow Brut:

(15) Ac yna y dodet y lleuein mabr a'r gorderi. Ac y bu aerua drom o pop parth.

(NLW 3036 (Mostyn 117): 21)

And then there was a great cry and noise and a severe battle from each part.

Tunc oritur clamor inter diuersas gentes, tunc crebri ictus inferuntur, tunc in utraque parte fit caedes dirissima.

Then shouts arose from the contending armies, blows were redoubled and there was terrible slaughter on both sides.

(HRB I 18: 382; Reeve \& Wright 2007: 24-5)

Although the scope of this article encompasses only the WP corpus, it should be mentioned that in Welsh poetry of the Middle Ages we also find frequent instances of trwm denoting battle (seven of thirty-six examples in the Hengerdd (cf. Isaac 2001); three of thirty-seven examples in the works of Beirdd y Tywysogion). ${ }^{4}$ We may consider 'Llym Awel':

(16) ry dieigc glev o lauer trum

A brave warrior can escape from many a battle

(EWSP 455, 502)

${ }^{4}$ I am indebted to Dr Ann Parry Owen for providing the data from the concordance. 


\section{Psycho-physiological domain}

Usages considered in this domain are related to physiology and unpleasant feelings.

\subsection{Quality of food + food: 'hard to digest'}

One such example is found in our sample, from the above-mentioned text Rhinweddau Bwydydd. Note here again the connection to the emotional domain.

(17) Kic eidyon, praffy mac a thrwm ac anawd y dodi, a melancoli a wna.

(Oxford Rawlinson B 467: 13v)

Beef is strong nourishment and heavy and difficult to digest; it causes melancholia.

(Jones 1955: 61)

Bovina caro multum est nutritiva et grossa et ad digerendum dura et melancoliam generat.

(Ostermuth 1919: 40)

\section{Emotional domain}

4.1. Emotional impact + abstract notion : 'oppressive, hard to bear'

One would expect that the metaphorical use of trwm with abstract notions in the emotional domain denoting something causing mental oppression would be quite frequent, the shift being so direct and transparent. The Irish data analysed by Dereza include such examples (see 4.1. in Dereza, this volume). In English we have heavy news or heavy silence, and in Russian this use is quite frequent: cf. тяжельй разговор 'difficult, distressing, sore conversation', тяжелое известие 'sad news' (Kustova 2004: 299). Surprisingly, our Middle Welsh prose sample provides no such examples. There are, however, plenty of examples in other parts of the emotional domain.

\subsection{Disposition + human being, psyche: 'sad, oppressed'}

In our sample trwm is used in this domain 33 times. Interestingly it is not just combinations with nouns that we are dealing here with, but rather more complex constructions which will be analysed in the following.

\subsection{1 bod $+T R W M+$ poss + 'mind' gan $\mathrm{X}$}

This construction is found eight times, and the range of words which I label 'mind' is diverse. Meddwl, ansawdd, bryd (twice), modd and hynt are found, and also the doublets meddwl a chalon, meddwl a bryd. Cf. Ystoria Bown de Hamtwn: 
(18) a thr6m oed genthi y challon a'e med6l a dechreu c6ynuan awnaeth hi

(NLW Peniarth 5: 133r)

and heavy was her heart and thought and she started complaining

The adjective itself is also often part of a doublet: trwm a gofidus, trwm a thost, trwm a thrist (twice, once in combination with the third adjective amharchus). Here I cite Ystoriau Saint Greal:

(19) phan gigleu y marcha6c hynny ef a uv dr6m a thrist ac amharchus gantha6 y hynt hyt na wydyat beth a wnaei. ac ymchoelut drachefyn ymeith a oruc ef.

(NLW Peniarth 11: 101v)

And when the knight heard that, he was sad and sorrowful, and ashamed of his state, so that he did not know what he should do; and he returned back.

Doubling of the whole structure is also possible, as here from Ystoria Bown de Hamtwn:

(20) G6edy gwelet o Josian ada6 garsi o'e gwarchad6 hi. tr6m oed genthi y bryt a dr6c oed y chyssyr.

(NLW Peniarth 5: 131v)

After Josian saw that Garsi was left to guard her, her mind was heavy and her spirit was sad.

Josian, la pucele o le cors honuré,/ vist k'ele dust estre si agardé,/ mult en fu dolent e desheyté.

(Stimming 1899: 60)

Josiane, the maiden famous for her beauty, saw she was to be closely watched, and it made her very miserable and sad.

(Weiss 2008: 54)

An intermediate step between the construction discussed above and the construction in which trwm is used as noun is probably found in the next example, in combination with the noun peth 'thing'. Consider this, from Ystoria Bown:

(21) y'm kyffes heb y bo6n. llyna beth tr6m a ffeth tost gennyf $i$ bot yn gymeint dy newyn di a hynny.

(NLW Peniarth 5: 133r)

By my confession, said Bown, it is a sad and bitter thing to me that your hunger is as great as that.

'Damisele,' dist Boves, "si damedeu me ament! / il me peyse mult, ceo sachez verement ["] 
'Lady,' said Boeve, 'God help me, I am very sorry for it - be sure of that.'

\subsection{2. bod trwm gan $\mathrm{X}$}

(Weiss 2008: 56)

The construction bod trwm gan $\mathrm{X}$ is used 14 times, as here from Ystoriau Saint Greal:

(22) Pan deuthum i y 6rtha6 ef heb·y la6nslot yd oed yn iach. a phei g6ypei ef $d y$ vot ti ual yd byt ef a vydei dr6m gantha6 ef a chan y brenhin.

(NLW Peniarth 11: 257r)

When I came from him, says Lancelot, he was well, and if he knew that thou art, as thou art, he would be grieved, and the King also.

(Williams 1987: 698)

Here again, doubling on several levels is possible; for example, the whole phrase may be doubled:

(23) A minheu pann gigleu y gount a oed arnat, trwm un gennyf, a doluryaw a wneuthum

(Thomson 1957: 22)

And when I heard of your affliction, I was saddened, and distressed.

(Davies 2007: 2)

Alternatively, we may find doubling of the adjective: e.g., trwm a thrist (three times), trwm a thruan, dolur a thrwm. Compare from Peredur:

(24) Yr pan y'th weleis gyntaf yd wyf y'th garv. a dolur yw gennyf a thrwm gwelet ar was kyn vonedigeidiet a thydy y dihenyd a wneir arnat $t i$ avory.

(NLW Peniarth 7: 10v)

Since I first saw you, I have loved you. And it pains and distresses me to see a lad as noble as you suffer the death that will be done to you tomorrow.

(Vitt 2010: 171)

In the White Book of Rhydderch version we see, "a thost yw gennyf" (Goetinck 1976: 37).

The synonyms used in doublets or variant readings from other manuscripts help us to pinpoint with more accuracy the emotion denoted. While in most cases it is sadness, a similar construction trymach gennyf $i$ definitely does not mean 'it is sadder', but, as Davies translates, "more tiresome": 
(25) 'Y rof i a Duw,' heb ef, 'ys trymach genyf $i$ noc a dyweit y gwyr na thewy di vrthyf $i$ ac na bydy vrth uyg kyghor.'

(Thomson 1997: 29)

'Between me and God,' he said, 'more tiresome to me than the men's words is the fact that you will not keep quiet for me, nor do as I tell you.'

(Davies 2007: 160)

Geraint says this to Enid, who is warning him about knights on their way, though he has asked her not to say a single word. We understand that it is not sadness he expresses by "trymach" because in the same situation later his emotions are described thus: "Glaschwerthin digius engiriawlchwerw a oruc Gereint" (Thomson 1997: 30) - "Geraint gave an angry, sarcastic, horrible, hateful laugh" (Davies 2007: 161).

\subsubsection{SUBJ + cymryd + yn drwm $a r+3 \mathrm{Sg} / \mathrm{Pl}$}

The final construction is SUBJ + cymryd + yn drwm ar + 3Sg/Pl // trwm y kymerth $X$ ar $+3 \mathrm{Sg} / \mathrm{Pl}$, found five times. It occurs three times in Ystoria Dared, once in Brut y Brenhinedd and once in Buchedd Mair Fadlen. Here I cite from Ystoria Dared:

(26) A thr6m y kymerth Jason a'e gedymdeithon arnunt greulonder Lammedon vrenhin.

(Red Book of Hergest: 1r)

And Jason and his companions became grieved because of the cruelty of King Lammedon.

It may be of significance that each time I was able to track the wording in the Latin original, it had the set phrase graviter ferre (cf. Oxford Latin Dictionary, s.v. graviter: 'with reluctance, pain or displeasure; (esp.) [grav]iter ferre (accipere, habere, tolerare), to take (something) ill, to be grieved or offended at'). Thus, the source for example above is:

Iason er qui cum eo venerant graviter tulerunt crudelitatem Laomedontis

(Meister 1873: 4)

Jason and those who came with him were offended by the cruelty of Laomedon

My suggestion is that this construction is based on the Welsh: this would be consistent with previous examples from the emotional domain, but here there is also interference from Latin in the use of the verb. 
The last usage of trwm in the emotional domain is its application to a person or group of persons directly, where in our sample it refers to inactivity, probably both morally and physically. In Wyth Rhan Pob Dyn, a translation of a text labelled often De homo octipartitus, ${ }^{5}$ the Latin piger is translated with a Welsh doublet llesc a thrwm:

(27) Os o'r daear y bydd y rann vwyaf ohonaw, llesc vyd a thrwm

(Hafod 16: 96)

If the greatest part of him is of the earth, he will be languid and heavy.

(Jones 1959: 383)

Si de limo terre supertraxerit, erit [que] piger in omni parte.

(Förster 1907: 408)

In some manuscripts of the Dingestow version of $\mathrm{BB}, y$ trymyon uileinllu stands for miserrimus uulgum:

(28) Ac ny orffowyssynt y gelynyon o u6r6 agheuolyon ergytyeu yn eu plith. Ac o u6r[6] bacheu g6rthuinya6c 6rth linyneu. Ac yuelly y trymyon uileinllu o'r kestyll ac o'r kaeroed a tynnynt hyt y lla6r. ${ }^{6}$

(NLW 3036 (Mostyn 117): 111)

And the enemies stopped not to deliver deathly blows in their midst and to throw barbed hooks on the ropes; and so they dragged the miserable peasants from [the walls of] the castles and fortresses down to the ground. Interea non cessant uncinata hostium tela, quibus miserrimum uulgus de muris trahebatur et solo allidebatur.

(HRB VI, 66; Reeve \& Wright 2007: 114-5)

At the same time the enemy ceaselessly used hooked weapons to drag the wretched herd off the walls and dash them to the ground.

The adjective under scrutiny was probably not the choice of the translator of the Dingestow version, since in the earlier manuscript we find trueinnyon, a more fitting equivalent to miserrimus:

Ac ny orffovyssei y gelynyon o wurv agheuolyon ergydyeu yn eu plith ac o wurv bacheu gvrthuynyavc vrth linynneu, ac yuelly tynnu y trueinnyon uileinllu hyt y llavr o'r kestyll ac o'r caeroed.

(Lewis 1975: 83)

\footnotetext{
${ }^{5}$ See Förster 1907-8; Tristram 1975.

${ }^{6}$ The syntax of this phrase is quite peculiar. [M]ileinllu is interesting as an example of a collective noun (cf. Poppe 2015); the adjective-noun sequence and congruence are characteristic of a translation style found in the Brutiau, as shown by Nurmio (2015: 169$71)$.
} 
However, this discrepancy between the earlier and later manuscripts is no obstacle, but rather an indication that trwm was actively used in this domain.

It should be noted that in the early poetry these usages of trwm referring to the person directly and not his/her mind or state are much more frequent. Cf. the famous example from 'Cân yr Henwr':

(29) wyf keuyngrwm. wyf trwm wyf truan

(EWSP 416, 475)

I am hunch-backed, depressed and wretched

5. Outside of the analysed domains

A specific usage for Welsh is the phrase sillaf drom, a syllable "containing a short vowel" (GPC online, s.v. trwm): there are three examples in the Red Book of Hergest and in Peniarth 20. For example, from Gramadegau'r Penceirddiaid:

(30) Sillaf drom a uyd pan uo dwy o'r kytseinanyeit vnry6 yn y diwed, ual y mae gwenn, llenn.

(Williams \& Jones 1934: 2)

A heavy syllable is when there are two equal consonants in the end, as in gwenn, llenn.

Cf. also trwm ac ysgafn: a fault in Welsh prosody consisting of an incorrect rhyme between a short and a long syllable (GPC online, s.v. trwm).

\section{Conclusions}

The aim of this article was to analyse the use of trwm on the basis of the Welsh Prose 1300-1425 project data. This data dictates that some of the senses analysed in GPC (s.v. trwm), like 'deaf, impaired (of hearing)' or '(heavily) pregnant (esp. of an animal)' and many others are unattested. Probably the relative scarcity of medieval data will not allow us to see the development of the polysemy of trwm in full detail. For the earlier period, I could only comment briefly on a few aspects of the usage of trwm in poetry, but before I leave this topic to be discussed elsewhere, I would like to draw attention to the following phenomenon.

Due to the importance of ambiguity and polysemy in Welsh poetry (cf. Johnston 2008), in at least five of the twenty-seven poems of Beirdd y Tywysogion where trwm is used, this adjective is used twice or more within a few lines, with the poets using a wide range of its senses. We may consider, for example Gwynfardd Brycheiniog, 'Canu i Ddewi': 
If a heavy fleet comes [with] terrifying greetings

Here we see first trwm used with llyghes, that is a fleet that can transport a lot of weight (parametrical domain), and again in the same line used with geiriau 'words', which we could paraphrase as 'causing unpleasant feelings' (emotional domain).

Comparison with the article of Dereza (this volume) shows how much resemblance there is between Irish in different stages of its development and the language of Middle Welsh prose. The question is how to explain this similarity. In a discussion of another case of polysemy in Irish and Welsh in Parina (2015: 24), I found very useful the following remark of Anna Zalizniak and her colleagues: "It is widely accepted that two languages can be similar in a certain aspect due to (a) inheritance, (b) contact, (c) universal tendencies, and (d) coincidence. Consequently, the presence in two languages of realizations of the same semantic shift can also be triggered by one of these four factors" (Zalizniak et al. 2012: 636).

A study of Breton and Cornish data would be required before claiming that some of the shifts are inherited from the common Celtic ancestor. On the other hand, many of the shifts that are shared between Celtic languages could be explained by universal tendencies. This is true for the emotional domain in the first place. Goddard and Wierzbicka (2007: 786) included in their definition of 'heavy' that a person thinking of a heavy object "can't not feel something bad in their body because of it". The concept of heaviness thus includes bad sensations. We find examples of the usage of 'heavy' in the emotional domain not only in European languages, but also, e.g., in Chinese (cf. Kholkina 2014: 305).

Language contact is another source for identical shifts. Especially interesting in this context is translational literature, since "translation constitutes a particular type of language contact, where the source language (SL) can have an influence on the recipient language (RL) as norms or structures are taken over in the process of translation" (Kranich et al. 2011: 11). In this discussion I have tried to identify, whenever possible, the Latin or French source text for translations. In many of the cases the equivalent demonstrated the same polysemy (gravis is very often the equivalent for Welsh trwm in parametrical and emotional domains). But does that mean that Welsh collocations are products of language contact or more specifically calques? Given the existence of the same collocations in languages with no contact with Welsh, such as Russian, we could rather suggest that many of these similarities can be explained by universal tendencies. There are however examples of specific 
constructions where the hypothesis of contact origin seems to be plausible. In the case of the construction trwm a gymerth $X_{I}(Y)$ ar $X_{I}$ its usage in translational texts exclusively and the closeness to the Latin construction graviter ferre suggests the possibility of influence through contact.

Small corpora definitely have their disadvantages, but being able to look at all the examples individually and understanding the texts enables the identification of individual factors, such as the preferences of some translators for certain expressions (like dyrnodeu trymyon in Ystoriau Saint Greal). Identifying the importance of such individual style is a further significant outcome of the study and suggests a direction for future research.

The last methodological consideration concerns historical origin and development and the synchrony of the structure of the analysed polysemy. Neither Dereza nor I propose any explanations for how these different usages are connected. Kustova (2004: 279-308) gives an interesting analysis of the structure of the polysemy of Russian тяжельй 'heavy': the links she proposes between different senses seem plausible, but this analysis may not be transferred to our data since we lack many of the collocations that serve as connecting links between usages attested in Russian and in Welsh and Irish. Is this due simply to the scarcity of data, or do different languages use different sequences of shifts that produce similar polysemy? This is a question whose answer will require lexical typological studies on a much larger scale. What we hope to have produced is a fair analysis of data from languages that are seldom considered in studies in semantic typology, and this is necessary in any linguistics with a bottom-up approach.

Philipps-Universität Marburg / Institute of Linguistics, RAS, Moscow

\section{References}

\section{Primary Sources}

EWSP - Rowland, J., 1990, Early Welsh Saga Poetry: A Study and Edition of the Englynion, Cambridge: D.S. Brewer.

Förster, M., 1907, 'Adams Erschaffung und Namensgebung', Archiv für Religionswissenschaft 11, 477-529.

Geoffrey of Monmouth, 2007, The History of the Kings of Britain. Latin text edited by Michael D. Reeve, translated by Neil Wright, Woodbridge: Boydell Press (Arthurian Studies 69).

Glare, P. G. W, 2012, Oxford Latin Dictionary, 2nd edn., Oxford: Oxford University Press. 
GPC Online, 2016, University of Wales Centre for Advanced Welsh \& Celtic Studies. http://www.geiriadur.ac.uk [accessed 21 June 2016].

Griffiths, B., Jones, D.G., 1995, The Welsh Academy English-Welsh Dictionary, Cardiff: University of Wales Press.

Isaac, G. R, 2001, Yr Hengerdd: Mynegeiriau Cyflawn. CD-ROM, Aberystwyth: Adran y Gymraeg, Prifysgol Aberystwyth.

Isaac, G.R., Kapphahn, K., Nurmio, S., Rodway, S., Sims-Williams, P., 2013, Rhyddiaith Gymraeg o Lawysgrifau'r 13eg Ganrif [Welsh Prose from $13^{\text {th }}$ c. manuscripts] Aberystwyth: Adran y Gymraeg, Prifysgol Aberystwyth. http://cadair.aber.ac.uk/dspace/handle/2160/11163 [accessed 21 June 2016].

Jones, I. B., 1955, 1958, 1959, 'Hafod 16 (A Mediaeval Welsh Medical Treatise)', Etudes Celtiques 7.1, 46-75; 8.1, 66-97; 8.2, 346-93.

Lefèvre, Y., 1954, L' Elucidarium et les lucidaires. Contribution, par l'histoire d'un texte, à l'histoire des croyances religieuses en France au moyen âge, Paris: De Boccard (Bibliothèque des Écoles Françaises d'Athènes et de Rome, 180).

Lewis, H., Diverrès, P.R.Y.M., 1928, Delw y Byd (Imago Mundi), Caerdydd: Gwasg Prifysgol Cymru.

Lewis, H., 1975, Brut Dingestow, Llandysul: J. D. Lewis a'i Feibion.

Luft, D., Thomas, P.W., Smith, D. M., 2013, Welsh Prose 1300-1425, Cardiff University. http://www.rhyddiaithganoloesol.caerdydd.ac.uk. [accessed 21 June 2016].

Meister, F., 1873, Daretis Phrygii de excidio Troiae historia, Lipsiae: Teubner.

Ostermuth, H. J., 1919, "Flores Diaetarum", eine salernitanische Nahrungsmitteldiätetik aus dem XII. Jahrhundert, verfaßt vermutlich von Johannes de Sancto Paulo, Borna-Leipzig: Robert Noske.

Richards, M., 1948, Breudwyt Ronabwy: Allan o'r Llyfr Coch o Hergest [The Dream of Rhonabwy: from the Red Book of Hergest], Caerdydd: Gwasg Prifysgol Cymru.

Richards, M., 1954, The Laws of Hywel Dda. The Book of Blegywryd, Liverpool University Press.

Stimming, A., 1899, Der anglonormannische Boeve de Haumtone, Halle: M. Niemeyer (Bibliotheca normannica... VII).

Thomson, R. L., 1957, Pwyll Pendeuic Dyuet. Dublin: Dublin Institute for Advanced Studies. (Mediaeval and Modern Welsh Series 1).

Vitt, A. M., 2010, Peredur vab Efrawc: Edited Texts and Translations of the MSS Peniarth 7 and 14 Versions. MPhil Thesis, Prifysgol Aberystwyth.

http://cadair.aber.ac.uk/dspace/bitstream/handle/2160/6118/Vitt Electron 
ic\%20MPhil\%20Thesis.pdf?sequence $=1 \& i$ s Allowed $=y$. [accessed 21 June 2016].

Weiss, J., 2008, Boeve de Haumtone and Gui de Warewic: Two AngloNorman Romances. Tempe, Arizona: Arizona Center for Medieval and Renaissance Studies (Medieval and Renaissance texts and studies. The French of England translation series: 3).

Williams, G. J., Jones, E.J., 1934, Gramadegau'r Penceirddiaid [Grammars of the Chief Bards], Caerdydd: Gwasg Prifysgol Cymru.

Williams, J.E.C., 1973/1974, 'Welsh Versions of Purgatorium S. Patricii', Studia Celtica 8/9, 121-94.

Williams, R., 1987, Y Seint Greal - The Holy Grail, Facsimile reproduction of the 1876 edition, Pwllheli: Jones (Wales) Publishers.

Williams, R., 1892, Selections from the Hengwrt Mss. Preserved in the Peniarth Library. Vol. II, London: Bernard Quaritsch.

Williams, St. J.; Powell, J. E., 1961, Cyfreithiau Hywel Dda yn ôl Llyfr Blegywryd, Caerdydd: Gwasg Prifysgol Cymru.

\section{Secondary Studies}

Day, J. P., 2010, Arfau yn yr Hengerdd a Cherddi Beirdd y Tywysogion [Weapons in Hengerdd and works of poets of the princes], Unpublished $\mathrm{PhD}$ dissertation. Aberystwyth University, Wales. (http://cadair.aber.ac.uk/dspace/handle/2160/4646).

Dereza, O., 2017, 'Physical Qualities in Goidelic: A Corpus Study of Polysemy and Collocability' (see pp. 83-100 of the present volume).

Falileyev, A., 2010, 'Delw y Byd Revisited', Studia Celtica 44, 71-6.

Goddard, C., Wierzbicka, A., 2007, 'NSM Analyses of the Semantics of Physical Qualities: sweet, hot, hard, heavy, rough, sharp in Crosslinguistic Perspective', Studies in Language 31.4, 765-800.

Griffith, A., 2017, 'Preliminaries to the Syntax of the Welsh Reduplicated Pronouns', in: Poppe, E., Stüber, K., Widmer, P., eds., Referential Properties and Their Impact on the Syntax of Insular Celtic Languages, Münster: Nodus, 9-37.

Höijer, M., 2014, Middle Welsh Personal Pronouns in ThirteenthCentury Manuscripts: Variation and Development, MPhil dissertation, Aberystwyth University.

Johnston, D., 2008, 'Semantic Ambiguity in Dafydd ap Gwilym's "Trafferth mewn Tafarn", Cambrian Medieval Celtic Studies 56, 59-74.

Kholkina, L., 2014, Качественные признаки в китайской лексике. Опыт типологического описания [Quality words in Chinese lexis. an attempt at a typological description], $\mathrm{PhD}$ thesis, Moscow State University. 
Kranich, S., Becher, V., Höder S., 2011, 'A Tentative Typology of Translation-induced Language Change', in: Kranich, S., ed., Multilingual discourse production: Diachronic and synchronic perspectives, Amsterdam: Benjamins, 9-44.

Kustova, G.I., 2004, Типь производных значений и механизмы языкового расширения [Туреs of secondary senses and mechanisms of linguistic extension], Moscow: Jazyki slavjanskoj kul'tury.

Mel'čuk, I., 1998, 'Collocations and Lexical Functions', in Cowie, A.P., ed., Phraseology: Theory, analysis and applications, Oxford: Clarendon Press, 23-53.

Parina, E., 2015, 'A Middle Welsh Translation of Flores dietarum', IndoEuropean Linguistics and Classical Philology 19, 623-9.

Parina, E., fc., 'Medical Texts in Welsh Translation: Y Pedwar Gwlybwr and Rhinweddau Bwydydd', in: Flood, V., Byrne, A., eds., Crossing Borders in the Insular Middle Ages, Turnhout: Brepols (Medieval Texts and Cultures of Northern Europe).

Petrovskaia, N., 2013, 'Delw y Byd: une traduction médiévale galloise', Études Celtiques, 39: 257-77.

Poppe, E., 2015, 'Luthers Darnach satzt sich das Volck zu essen vnd zu trincken vnd stunden auff spielen aus Sicht frühneukymrischer Bibelübersetzungen', in: Schuster, B.-M., Dogaru D.J., eds., Wirksame Rede im Frühneuhoch-deutschen: Syntaktische und textstilistische Aspekte, Hildesheim, Zürich, New York: Georg Olms Verlag, 131-52.

Reck, R., 2010, The Aesthetics of Combat in Medieval Welsh Literature, Rahden/Westf: VML Verlag Marie Leidorf.

Sims-Williams, P., 2011, Rhai Addasiadau Cymraeg Canol o Sieffre o Fynwy: Darlith Goffa J. E. Caerwyn a Gwen Williams [Some Middle Welsh adaptations of Geoffrey of Monmouth: Lecture in memory of J.E. Caerwyn and Gwen Williams], Aberystwyth: Canolfan Uwchefrydiau Cymreig a Cheltaidd Prifysgol Cymru.

Sims-Williams, P., 2016, "The Welsh Versions of Geoffrey of Monmouth's "History of the Kings of Britain"', in: Harlos, A., \& Harlos, N., eds., Adapting Texts and Styles in a Celtic Context. Interdisciplinary Perspectives on Processes of Literary Transfer. Studies in Honour of Erich Poppe, Münster: Nodus. 53-74.

Zalizniak, A.A., Bulakh, M., Ganenkov, D., Gruntov, I., Maisak, T., Russo, M., 2012, 'The Catalogue of Semantic Shifts as a Database for Lexical Semantic Typology’, Linguistics 50.3, 633-69. 